\title{
Introduction: Cultural and Religious Boundary-Crossing in Early Modern Spain
}

\author{
MIRIAM BODIAN
}

University of Texas at Austin, Austin, TX, USA

E-mail:bodian@austin.utexas.edu

Accepted: 14 July 2021 / Published online: 17 December 2021

This issue of Jewish History brings together the work of scholars who are exploring the entanglement of traditions and identities among the three major religio-ethnic groups in early modern Spain. These scholars are participating in a broad shift in early modern Spanish historiography in recent decades. It challenges a traditional conception according to which the historical trajectories of "Old Christians," judeo-conversos (henceforth "conversos"), and moriscos (baptized Muslims and their descendants) were essentially separate. According to this conception, each population developed within its own rather fixed psychic and cultural boundaries.

The scholarly segregation of these populations has been the norm in both of the major traditional conceptualizations of early modern Spanish history. One, which goes back to medieval times and held sway in the conservative academic culture of modern Spain, perpetuates a view of Spain as inherently Catholic and European. The other, with deep roots in the Protestant world, presents early modern Spain as a stagnant backwater where cultural creativity and dissent were crushed by a repressive church, state, and inquisition. Different as they are, both conceptualizations have had the effect of submerging early modern Spain's religio-ethnic minorities beneath the surface of "mainstream" Spanish history.

It is true that the influential, if idiosyncratic, work of Américo Castro in the 1940s and 50s challenged both paradigms. Castro envisioned Spanish society and culture as having been shaped from the Reconquista onward not, as others would have it, by the dominance of the majority population of Spanish Catholics, but by the dynamic interactions of Catholic, Jewish, and Muslim "castes." Today, the speculative, tendentious approach of Castro, with its thinly-veiled racism, has been largely discredited; however, in its time, Castro offered a precocious vision of a Spain whose major, enduring contours emanated from a mixing of cultures. 


\section{Jewish Historiography}

Traditional Jewish scholarship produced an alternate perspective on early modern Spain. It has focused on a single population (the conversos), a single institution (the Inquisition), and a single form of religious dissent (cryptoJudaism). It has represented the history of the forcibly baptized Jews and their descendants in the Iberian Peninsula as an intrinsic part of centuries-long Jewish diaspora history. It served to corroborate the familiar contours of Jewish history, resonating with the themes of persecution and resistance in Jewish collective consciousness. Whether we read the work of major Jewish historians who have studied Spanish converso experience (Cecil Roth, Yitzhak Baer, Yosef Hayim Yerushalmi, Benzion Netanyahu, and David Nirenberg, among others) or textbooks and popular narratives of Jewish history, we are presented with a relationship between the dominant Spanish-Catholic population and descendants of baptized Jews that was relentlessly antagonistic.

This is hardly surprising. The broad contours of Jewish/converso existence in early modern Iberia were defined by the traumatic experiences of coerced mass conversion, systematic inquisitorial persecution, expulsion, and racial discrimination. The sources include a large corpus of virulent anticonverso propaganda as well as an ample stockpile of bitterly anti-Catholic converso utterances; these too have reinforced the image of Old Christians as persecutors and of conversos as victims. Among Jewish scholars active in the post-Holocaust period, a focus on the traumatic aspects of converso existence (including exclusion based on "purity of blood" laws) was understandable. Yet there was a more fundamental reason for the highlighting of Old Christian persecution and converso resistance, namely the persistence of a long historiographical tradition that holds Jewish society to be existentially at odds with Christendom.

It was only in the 1980s and 1990s - at a time when historians across fields were becoming aware of the degree to which scholars had tended to "essentialize" ethnoreligious groups, overlooking the frequent everyday intimacy among them - that scholars of Jewish history began acknowledging the fluidity and variability of Jewish-Christian relations, even in periods when intergroup tensions ran high. ${ }^{1}$ The growing prevalence in these years of a theoretical notion of "identity" that was inherently unstable and multilayered, along with the increasing perception of group boundaries as being malleable and constantly negotiated, further eroded the clear-cut distinctions that once prevailed.

\footnotetext{
${ }^{1}$ Perhaps the most influential revision of thinking about the contours of Jewish-Christian relations in Spain has been David Nirenberg, Communities of Violence: Persecution of Minorities in the Middle Ages (Princeton, 1996; rev. ed. 2015).
} 
Despite the overall shift toward a less monochromatic representation of conversos, a new current of scholarship emerged in the 1990s that once again depicted conversos in essentialist terms-not, as had earlier been the case, as a defamed and persecuted population, but as a population with unique and identifiable cognitive and psychic characteristics. Scholars pursuing this line of inquiry used the term "marranism" to refer to the psychic phenomenon they described. Some regarded "marranism" as nothing less than a precursor to "modernity" itself (in the sense of a modern sensibility). ${ }^{2}$ To be sure, this body of scholarship acknowledged —indeed, required - a conceptualization of individual identity as potentially conflict-ridden and unstable. Yet, by singling out conversos as the exclusive bearers of a "marrano" sensibility, it had the effect of giving new life to a view of the conversos as a distinct and unique population.

Hispanists who have devoted essays and monographs to converso history have also, like scholars of Jewish history, tended to study conversos in isolation from other populations. But they have done much to mitigate the once conventional image among Jewish scholars of the conversos essentially as a population of crypto-Jews. While there is no single thrust to their work-their assumptions, methodologies, and interests vary widely - they have played an important role in throwing light on the otherwise neglected lives of assimilated conversos, relying on local and regional archival documents as well as Inquisition files. ${ }^{3}$ They have shown that some converso families, faced with stigma and discrimination, succeeded in gaining official certification that their blood was "pure," and that others married into the nobility, entered the Church, gained privileged positions on municipal councils, or otherwise blended into Old Christian society.

While such studies have served to balance the picture, some have overemphasized converso assimilation, representing converso identity in strictly socioeconomic terms. "La clase social de los conversos" - the title of an important work published in 1955 by Antonio Domínguez Ortiz-is an early

\footnotetext{
${ }^{2}$ The most influential work in this vein is Yirmiyahu Yovel, The Other Within: The Marranos; Split Identity and Emerging Modernity (Princeton, 2009). For critical reviews of the work see David Nirenberg, "Unrenounceable Core," London Review of Books 31, no. 14 (2009): 1617; Miriam Bodian, American Historical Review 115 (2010): 616-18; and Yitzhak Melamed, Journal of Modern History 83 (2011): 198-200.

${ }^{3}$ An early contribution is that of Francisco Márquez Villanueva, "Conversos y cargos concejiles en el siglo XV," Revista de Archivos, Bibliotecas y Museos 63 (1957): 503-40. For a more recent study in English, see Linda Martz, A Network of Converso Families in Early Modern Toledo: Assimilating a Minority (Ann Arbor, MI, 2003). For a discussion of the use of noninquisitorial documents for the study of conversos, see Enrique Soria Mesa, "Los judeoconversos granadinos en el siglo XVI: Nuevas fuentes, nuevas miradas," in Estudios sobre Iglesia y Sociedad en Andalucía en la Edad Moderna (Granada, 1999): 101-9.
} 
example of this approach. The author describes the New Christian population as an "educated, wealthy and active minority" that was concentrated in urban areas and in certain occupations (administrative functions, commerce, crafts) and that was separated from the majority society by "an invisible frontier" of discrimination. ${ }^{4}$ Let me add that Domínguez Ortiz was by no means doctrinaire, and what he meant by "social class" was rather vague. In a far more dogmatic vein, the Portuguese scholar António José Saraiva published a work in 1956 that made the radical and controversial argument that the Portuguese Inquisition was in effect an instrument of class struggle. His work dismissed as disingenuous the religious or racial justifications that contemporaries gave when anti-converso measures were adopted. In his view the Portuguese New Christian mercantile bourgeoisie threatened the ruling aristocratic class, which fought back by establishing an institution that, while claiming to be a guardian of Catholic orthodoxy, in fact aimed to crush the power of the class of New Christians of Jewish descent. ${ }^{5}$ Whether "social class" has been conceived loosely or dogmatically, however, the use of this term has served to support the impression that Iberians with Jewish ancestry, scattered throughout the Peninsula, comprised a cohesive and rather homogeneous urban stratum.

In fact, the trajectories of assimilation were myriad. As early as the fifteenth century many conversos in Spain were conforming - and sometimes deeply committed-Catholics. But they were not necessarily conventional Catholics. It is well known that conversos played an entirely disproportionate role in fifteenth- and sixteenth-century circles where new, interior forms of Catholic spirituality were developed, forms that harked back to Pauline teaching but also drew from Reformation currents. ${ }^{6}$ Recent work has helped elucidate how the social degradation experienced by conversos provided a motivation for adopting this new, egalitarian spiritual orientation. ${ }^{7}$ CryptoJews could also be attracted to it. It was by reading Catholic spiritual literature in this vein (about which see the essay of Mercedes García-Arenal in this issue) that the dogmatizing judaizer Luis Carvajal integrated aspects of this

\footnotetext{
${ }^{4}$ Antonio Domínguez Ortiz, La clase social de los conversos en Castilla en la edad moderna (Madrid, 1955), 139-54, quotes at 139-40.

${ }^{5}$ The first edition of this quite polemical work was published in Portuguese as Inquisição $e$ cristãos novos (Lisbon, 1956), and was followed by five subsequent editions. It has been published in English as The Marrano Factory: The Portuguese Inquisition and Its New Christians 1536-1765, trans. Herman Prins Salomon and Isaac S. D. Sassoon (Leiden, 2001).

${ }^{6}$ Marcel Bataillon brought this to light in his magisterial work, Erasme et l'Espagne (Paris, 1937).

${ }^{7}$ See Stefania Pastore, Una herejía Española: Conversos, alumbrados e Inquisición (1449-1559) (Madrid, 2010).
} 
spirituality into his followers' practice and understanding of Judaism. ${ }^{8}$ Research on this protean trend, which drew richly from wider European trends, and for convenience is referred to as alumbradismo, has served to underscore the vitality of religious innovation in early modern Spain, as well as the need to look across religoethnic divides in order to grasp its contours.

\section{Morisco Historiography}

Scholarship on moriscos has long been similarly partitioned off from the study of other Iberian populations. (Not coincidentally, my own assessment here relies heavily on the work of others. ${ }^{9}$ ) As with conversos, scholars have tended to treat the history of the moriscos as a distinct subfield with its own contours. To be sure, a few scholars have skillfully examined both converso and morisco minorities. ${ }^{10}$ Yet until recently they have usually done so in separate studies dedicated to one group or the other. It is true that scholars have noted the evident, if partial, parallels between morisco and converso history. ${ }^{11}$ But, in general, as James Amelang has observed, conversos and moriscos have been treated in "two largely separate historiographies that often seem to ... live largely with their backs to each other."12

The historical trajectory of the moriscos differs most strikingly from that of the conversos in that the former were forcibly expelled en masse from Spain. Despite the fact that they had been baptized for generations, they were uprooted in the years 1609-1614 and scattered mainly to Muslim lands. In contrast to the conversos, much of whose history has been written by Jewish scholars, morisco history has overwhelmingly been written by Spanish historians (or other western Hispanists). This has not been due to Arab historians' lack of interest in Spain's Muslim population. However, most works written in Arabic on Muslim Spain have dealt with the centuries when that

\footnotetext{
${ }^{8}$ See Miriam Bodian, Dying in the Law of Moses: Crypto-Jewish Martyrdom in the Iberian World (Bloomington, IN, 2007), 47-78.

${ }^{9}$ I am particularly indebted to the review essay by Mercedes García-Arenal, "Religious Dissent and Minorities: The Morisco Age," Journal of Modern History 81 (2009): 888-920.

${ }^{10}$ Mercedes García-Arenal points to the "distinguished exceptions" of Julio Caro Baroja, Antonio Domínguez Ortiz, and Francisco Márquez Villanueva in her "Religious Dissent and Minorities," 902-3. For further works that have dealt with both populations, see James S. Amelang's pioneering work, Historias paralelas: Judeoconversos y moriscos en la España moderna (Madrid 2011), 183-84.

${ }^{11}$ For a deft and concise analysis of parallels and differences, see James S. Amelang, Parallel Histories: Muslims and Jews in Inquisitorial Spain (Baton Rouge, LA, 2013), the abridged English translation of Historias paralelas.

${ }^{12}$ Amelang, Parallel Histories, x.
} 
society flourished; few have been dedicated to the century of decline after the mass conversions of the sixteenth century. This has produced different fault lines in converso and morisco history, respectively. While in the case of converso scholarship there has sometimes been a struggle between two competing national narratives (Jewish and Spanish), in the case of the moriscos the struggle has mainly been over the shape of one national narrative - the Spanish. Traditional early modern Spanish historiography, which viewed Spain as fundamentally European and Christian, rendered moriscos, in one scholar's words, as "exotic and strange, almost out of place in their own homeland, and marginal to the great events of the Hispanic imperial drama." 13 However, a cluster of scholars in recent decades (including several featured in this issue) have challenged this view, envisioning Spain as the moriscos' homeland, a region where their ancestors had put down extensive roots many centuries earlier.

The need to reconceive Spanish history in a way that demarginalized moriscos was articulated in an influential work by Francisco Márquez Villanueva, who since 1960 sought to demonstrate how little early modern Spain conformed to its fixed historiographical image. ${ }^{14}$ Márquez argued that the necessity felt by Spaniards to justify the expulsion of hundreds of thousands of baptized persons whose only crime was their Muslim ancestry had shaped the historical narrative about the morisco presence from the start. According to the prevailing narrative, he noted, there was never really any other option but to expel the moriscos, because they had proved unassimilable. This convenient assumption about the moriscos persisted even well after the emergence of modern Spanish scholarship in the nineteenth century.

Márquez also argued (as have others) that disproportionate reliance on Inquisition documents has reinforced the stereotype of the unassimilable morisco. Much as in converso scholarship, reliance on the plentiful files of the Inquisition to study moriscos, who were typically charged with adhering to Muslim practices, has tended to magnify the conflictive aspects of morisco/Old Christian relations. It is no accident that historical overviews of Spanish history often deal with moriscos mainly as a "problem" for Spanish society. To be sure, more progressively minded historians, critical of the religious and cultural coercion exercised by Spanish authorities in early modern Spain, have viewed morisco resistance sympathetically. Either way, however - that is, whether moriscos are viewed as troublemakers or victims seeking justice- they appear in a posture of conflict with Old Christian society.

\footnotetext{
${ }^{13}$ L. P. Harvey, Muslims in Spain (1500-1614) (Chicago, 2005), viii.

${ }^{14}$ Francisco Márquez Villanueva, El problema morisco (Desde otras laderas) (Madrid, 1998), 98-195.
} 
That many people imagine the morisco population to be an undifferentiated mass-poor, rural, Arabic-speaking, resistant to Spanish-Catholic culture, and inclined to ally themselves with Muslim powers-also has to do with the fact that scholars have tended to focus on the dense, rural, and unintegrated moriscos of Valencia and Granada (where moriscos launched a serious rebellion in 1568-70, after the use of Arabic was banned), to the neglect of the more assimilated moriscos of Castile and Aragon, who are often difficult to identify. Summarizing an agenda that she has singularly advanced, Mercedes García-Arenal a decade ago wrote of the need to "endow Morisco history with a complexity it currently lacks." 15 Recent research has brought into view the activity of moriscos who were no longer the manual workers and farm laborers they had been at the time of the mass conversions, but whose ranks included priests, university graduates, nobles, and civic functionaries. A trove of local documents has revealed the considerable social mobility over the course of the sixteenth century of the moriscos in the Castilian village of Villarrubia, as well as these moriscos' readiness to take action to preserve their rights. ${ }^{16}$ An outstanding example elsewhere of morisco activism is that of the Granadine morisco Francisco Núñez Muley, who wrote a trenchant memorandum to Crown officials protesting the restrictions placed on traditional morisco customs and habits that did not violate Christian norms. ${ }^{17}$

The work of revision has entailed turning to new sources and expanding the field of study. A particularly rich source for recent research is the aljamiado literature, a morisco literature in vernacular Spanish with Arabic elements, written in Arabic script. Although aljamiado texts were systematically confiscated by the Inquisition, some two hundred of them, hidden away, have survived. These texts reveal a creative vitality in the morisco orbit that has often been assumed not to exist. In the wake of a massive assault on their sense of collective identity, authors of this literature engaged in a process of recovery and reconstruction, one that entailed the linguistic and cultural hispanization of Islam (a phenomenon with parallels in crypto-Jewish circles) in

\footnotetext{
${ }^{15}$ García-Arenal, "Religious Dissent and Minorities," 892.

${ }^{16}$ For a work that aims to demonstrate the diversity of morisco voices, see Bernard Vincent, El río morisco (Saragossa, 2006). See also the revealing research of Trevor J. Dadson, Tolerance and Coexistence in Early Modern Spain: Old Christians and Moriscos in the Campo de Calatrava (Woodbridge, UK, 2014).

${ }^{17}$ See Vincent, El río morisco, 89-104, chapter titled "Algunos voces más: De Francisco Núñez Muley a Fátima Ratal." And see, in English, the introduction by Vincent Barletta to his translation of this work, A Memorandum for the President of the Royal Audiencia and Chancery Court of the City and Kingdom of Granada (Chicago, 2007), 1-54.
} 
an effort to preserve the traditions of Muslim Spain. ${ }^{18}$ Of particular interest, also, is a set of forged lead tablets found in Granada shortly before the start of the expulsion in 1609 , which have now been closely studied. ${ }^{19}$ These texts, written in Arabic, were supposedly authored in the first century by disciples of Saint James, who according to tradition had brought Christianity to Iberia. They offer a narrative of the Spanish past in which Arabic culture-including the Arabic language and elements of Islam-are integrated into a Christian framework. The morisco forgers of these tablets perhaps hoped to mitigate Crown and Church measures that were intended to eliminate Arabic and cultural habits associated with Islam (about which see David Scotto's article in this issue).

Interest also has turned to the experience of moriscos after their expulsion from Spain. Here, again, there is a parallel with converso history. However, while sources abound and much has been written on the ex-converso diaspora, morisco exile sources - and research based on them-is more limited, partly because the great majority of the morisco exiles were absorbed relatively quickly into the Muslim cultures of their places of settlement. Yet recent work by scholars, building on the work of Mikel de Epalza, has contributed to a multifaceted picture of morisco life after the expulsion, not only in North African and Ottoman lands but in Spain, where some returned or managed to remain. The fact that morisco exiles had lost so many of their traditions that they had to undergo a process of "islamization" (akin to the "rabbinization" of ex-conversos), along with the fact that they continued to write in Spanish and sometimes identified as Andalusian nobles, attests to the degree to which they had been hispanized. ${ }^{20}$

\section{This Issue}

In sum, recent studies have produced a wealth of evidence that, despite the Crown's enormously powerful apparatus of religious control, early modern Spain was a site of considerable religious ferment. The sometimes-radical

\footnotetext{
${ }^{18}$ See Luce López-Baralt, La literature secreta de los últimos musulmanes de España (Madrid, 2009), and the introduction to María Teresa Narváez Córdoba, ed., Tratado (Tafsira) del Mancebo de Arévalo (Madrid, 2003).

${ }^{19}$ See Mercedes García-Arenal and Fernando Rodríguez Mediano, Un oriente español: Los moriscos y el Sacromonte en tiempos de Contrarreforma (Madrid, 2010); English translation, The Orient in Spain: Converted Muslims, the Forged Lead Books of Granada, and the Rise of Orientalism, trans. Consuelo López-Morillas (Leiden, 2013).

${ }^{20}$ See, inter alia, Luis Bernabé Pons, Los moriscos: Conflicto, expulsion y diaspora (Madrid 2009); Mercedes García-Arenal and Gerard Wiegers, eds. Los moriscos: Expulsión y diáspora: Una perspectiva internacional, 2nd ed. (Valencia, 2016).
} 
reevaluation of religious assumptions in early modern Spain, to some degree fed by humanist and Italian-Catholic innovations from abroad, had much to do with the exposure of Spaniards to three religious traditions. The discovery of manifold permutations of belief (or unbelief) in all sectors of society has contributed to what Seth Kimmel has called "a dramatically revised sense of the place of Spain ... within the broader European history of religious reform." ${ }^{21}$ The Inquisition, however long its reach, could not prevent human minds from productively violating the orthodoxies it tried to enforce. The very existence of competing faiths in a Spain that systematically persecuted infidels and heretics - that was still, in effect, a multireligious society-had an impact, however immeasurable, on the way Spaniards of all backgrounds interpreted their experience. ${ }^{22}$

This issue of Jewish History grew out of two panels at the annual meeting of the Renaissance Society of America Annual Meeting in New Orleans in March 2018. The essays it includes explore the impact of cross-religious interchange in the life and imagination of early modern Spanish subjects. The authors, while attentive to research that has already been done, ask new questions and work with new sources. For readers who are unfamiliar with this relatively new vein of scholarship, the essays in this issue can serve as an introduction. For specialists, they further elaborate an emerging cultural landscape that has proved to be anything but stagnant.

The opening article is by Mercedes García-Arenal, a leading scholar of morisco history and an important proponent of an integrated approach to the spiritual and intellectual history of early modern Spain. The mass conversions of Jews and Muslims were followed by the confiscation of their religious texts, depriving the converts and their descendants of access to the foundational texts of their traditions. In her essay, García-Arenal gleans from the riches of the inquisitorial archives to examine a specific phenomenon found among judaizing conversos. Lacking access to Jewish texts, the latter made use of Catholic sources (among them, polemical and inspirational works) to learn about Judaism, reading them "against the grain." So important was this stratagem that inquisitors began to discern, on the basis of their interrogations, a specific repertoire of such texts. To prevent their use by judaizers, the Inquisition added many of these essentially orthodox works to indexes of forbidden books. The removal of access to these works had the unintended

\footnotetext{
${ }^{21}$ Seth Kimmel, "The Morisco Question: Methodology and Historiography," History Compass 17, no. 4 (2019): 6.

${ }^{22}$ See Felipe Pereda, Images of Discord: Poetics and Politics of the Sacred Image in 15th Century Spain (London, 2018), for a discussion of how the choice of religious statuary used in evangelizing the forced converts and their descendants had an impact on Old Christian piety. And see the contribution to this issue of Mercedes García-Arenal for a parallel phenomenon related to book censorship.
} 
consequence of altering the religious experience even of pious, conforming Catholics. García-Arenal examines this phenomenon, which she richly illustrates, in the broader context of an intensely polemical and evangelizing early modern Spanish environment.

Yonatan Glazer-Eytan, in his essay, explores how Spanish-Catholic narratives and images sometimes depicted Muslims or moriscos committing imagined acts of sacrilege of a kind typically associated exclusively with Jews or conversos-in particular the supposed act of desecrating the host. He assembles evidence showing that on some occasions the Inquisition, too, accused moriscos of host sacrilege. Although Muslims lacked the motive that best "explained" Jewish behavior in host desecration narratives-that of deicidal impulses - they nevertheless appeared analogous to Jews in their stubborn infidelity, their hostility to Christianity, and their supposed skill at practicing magic. The author suggests that in tales whose fundamental aim was to prove the truth of the doctrine of transubstantiation (through a miracle that followed the desecration), the religio-ethnic identity of the infidel who perpetrated the crime might be of secondary importance. Widening his lens, Glazer-Eytan demonstrates how Jews and Muslims were lumped together in other contexts as well, including that of medieval restrictive legislation. Analyzing images and texts dating from the thirteenth to the seventeenth centuries, he suggests an association of Muslims and Jews in the Christian imagination, despite the crucial differences in Christian attitudes toward each of these religious minorities.

The following essay by Davide Scotto deals with a quite different case of Christian thinking that also, however, analogized Jews and Muslims. Scotto examines the evangelization strategies of the prominent Hieronymite friar Hernando de Talavera, archbishop of Granada, and challenges the accepted scholarly view that Talavera adopted a uniquely tolerant attitude toward coercively baptized infidels. In fact, he argues, Talavera's approach to conversion was in some respects quite compatible with that of his contemporaries. Scotto analyzes in detail the taxonomy of ritual practice and worship as it emerges from Talavera's program of evangelization for both conversos and moriscos. What he perceives underlying Talavera's works is a universal template of religious behavior, one that Talavera applied to both Judaism and Islam (and perhaps to infidel religions in general). The plan was not geared to effecting a spiritual conversion in the hearts and minds of forced converts. Rather, it aimed to eliminate the everyday rites and customs that had been integral to the converts' previous lives, replacing them with Christian practices. Scotto makes the argument that Talavera's supersessionist understanding of his plan, though rhetorically Pauline, in fact represented a basic deviation from the teachings of Paul.

In the final essay, Miriam Bodian opens with a historiographical survey showing how, from the 1980s onward, scholars have come to recognize 
the pervasiveness, richness, and fluidity of heterodox ideas in early modern Iberia. The same ideas that, when conversos spoke them, were categorized by inquisitors as "judaizing" could also be found among heterodox Old Christians - though in the latter case they would likely be categorized as "blasphemy" or heretical "proposiciones." Skeptical ideas-once largely absent from the history of early modern Spain — have been found scattered in Inquisition documents, uttered by Old and New Christians alike. The profusion of such evidence has led scholars to think more deeply about the paths by which heterodoxy originated and circulated. Bodian's essay continues with an examination of a set of unresolved issues raised by this evidence. Do the popular criticisms of Catholic doctrine uncovered by the Inquisition precociously anticipate the European Enlightenment, or did such criticisms perhaps exist, though undocumented, everywhere in Reformation Europe? Put differently, was the Inquisition uncovering religiously skeptical and relativistic currents that were latent and ubiquitous in European cultures, or did these currents first appear in Iberia, where they signaled an early shift in the direction of "modernity"? Can we reliably explain what lay behind the heterodox expressions recorded by the Inquisition? And are we able accurately to assess their scope?

Publisher's Note Springer Nature remains neutral with regard to jurisdictional claims in published maps and institutional affiliations. 